\title{
THE IMPORTANCE OF SOCIAL TOURISM DEVELOPMENT IN GEORGIA
}

\author{
Larisa Dolikashvili, \\ Doctor of Economics, Associate Professor, \\ Georgian National University SEU
}

\begin{abstract}
Tourism is a global economic, social and cultural phenomenon of the modern world. Tourism meets human needs for cultural, physical, cognitive and spiritual development. Its key objectives are determined by specific social and cultural functions. In terms of the financial backing, tourism is divided into two types:
\end{abstract}

- Commercial (based on personal or corporate funding);

- Social (based on state or charity funding).

Commercial tourism is focused on making a profit by travel companies, vital to their further expansion and development. In the process of profit maximization, companies try to find the optimal ratio between costs and tourism product prices. The tourism services, they offer, are mainly focused on high and middle income individuals, who can afford to fully cover their travel expenses.

Social tourism is subsidized from the opportunities allocated to meet the social needs essential to creating travel opportunities for students, young people, retirees and veterans. This category of people, as the least able-bodied segment of the population, is provided with the appropriate opportunities by the state and nongovernmental organizations, or charitable foundations. This position is reinforced by the Manila Declaration on World Tourism, which states that "social tourism is a goal that society should pursue in the interests of those citizens who are least privileged in exercising their right to leisure" .

The concept and types of social tourism are different in different countries. In some countries, civil servants, the military and other categories enjoy the opportunity to travel at the expense of the budget, while in others it is subsidized, for example, by trade union funds. Companies that arrange such tours receive subsidies from the state, which allows them not to raise prices during the holidays.

The paper discusses the positive experience of developed countries in implementing social tourism development programs, the classification of target population groups in social tourism, development prospects in this field of tourism and positive factors.

Keywords: Social Tourism, Subsidies, Social policy, Charitable Foundations, Legislative Regulation.

\section{Introduction}

Social tourism is defined as travel subsidized, with funds allocated by the state for social needs. The state provides certain categories of tourists with social benefits. The priority types of social tourism include:

- Tourism for children and youth;

- Amateur (sport and health);

- Health and well-being;

- Ecological, cultural and educational;

\footnotetext{
${ }^{1}$ World Tourism Organization (UNWTO) UNWTO Declarations | Manila Declaration on World Tourism (UNWTO), Madrid, Spain. p.5. https://www.univeur.org/cuebc/downloads/PDF\%20carte/65.\%20Manila.PDF [1. s. 30.09.2021].
} 
- Family travel;

- Tourism for veterans;

- Tourism for people with disabilities;

- Tourist visits of foreign compatriots, international exchange in the field of social tourism.

In particular, some categories of the community are entitled to free sanitary-spa treatment. Ensuring access to tourist recreation for all, including large families, young people and the elderly, requires the development and implementation of a number of specific measures, as well as defining the social tourism policy by the state, creating social infrastructure, adopting legislative and normative acts, providing systems and mechanisms for assistance to the low-income segments of the population, upskilling the workers of the social tourism system.

The development of social tourism is important primarily to improve the quality of life of the country's population. Thanks to this sphere of tourism, not only the general cultural development of the poor segment of the population increases, but also its health, while the social level of tension in the society decreases.

Travel is a significant problem for this segment of the population. It is designed for low-income families, who have the right to travel but cannot fully exercise that right.

Social tourism, which focuses more on social aspects than economic factors, is able to facilitate the creation or replication of tourism destinations that meet the criteria of economic, social and environmental sustainability.

The problems of social tourism development in Georgia start with the fact that there are no regulatory documents in the tourism legislation, which determine which tourist, for which trip, where and when, will be able to receive budget funds. Based on the experience of foreign countries, the state should define a social tourism policy in this area, which includes the adoption of laws and regulations, the creation of social infrastructure, the provision of systems and mechanisms for assistance to low-income groups, upskilling of social tourism workers.

\section{The essence, functions and objectives of social tourism}

Tourism can have a huge impact on the health of the elderly and people with disabilities, and is an important factor in counteracting hypokinesia, which has a devastating impact on people's health and their psyche. Movement-related limitations significantly reduce life opportunities, leading to depression, despair, stress, and loss of self-confidence. Physical training and health are maintained through tourism, psychosomatic therapy and prevention. Tourism creates a full-fledged communication environment in which a person with problems interacts with different people, establishes social contacts, and has the opportunity to play a variety of social roles. Tourism eliminates feelings of loss of dignity, inferiority and unites socially vulnerable people, the elderly and the disabled in society.

Social tourism is any type of tourism that is paid for from the funds allocated for social needs. Social and economic tourism aims to create appropriate conditions for leisure and travel for the low-income segments of the population (young people, schoolchildren, people with disabilities, pensioners, large families, orphans, children of orphanages, and the disabled). Subsidies for this type of tourism can be allocated not only by the state, but also by various governmental and private, as well as various charitable organizations.

A distinctive feature of social policy is that it is human-centered, while economic policy is focused on economic growth and the expansion of material wealth. Social policy has a significant impact on the development of tourism. Social measures can regulate the demand for tourism services in the following ways: 
- By regulating the right to rest, the state guarantees the employees of temporary regular dismissal. At the same time, setting vacation and holiday dates at different times promotes a balanced distribution of demand for tourism services;

- By distributing income in the society, the modern welfare state strives to achieve a high level of prosperity for the possible large number of citizens, for which it carries out the distribution of income through various means and incentives;

- By stimulating the development of social tourism.

The social functions of tourism are carried out in recreational activities aimed at maintaining and strengthening health, restoring vitality, promoting the harmonious development of the individual and its creative self-expression. Adaptation and integration of individuals in the social life of the community represents a key function of social tourism.

The concept of social tourism is based on three fundamental principles:

- Providing recreation for every member of the community with the involvement of low-income people in the field of tourism;

- Subsidizing low-income tourism;

- Active participation of state, municipal, public and commercial entities sin the development of tourism.

The field of social tourism is represented by free and preferential vouchers in sanatoriums, holiday homes, tourist centers, free and preferential travel, special transport tariffs, and tax and customs benefits. The development of social tourism facilitates the construction of tourism infrastructure for tourists with special needs. The most important tasks of social tourism can be identified as:

- Organizing affordable vacations to improve health for socially vulnerable groups of the population;

- Creating a barrier-free environment for people with disabilities.

The provision on social tourism is enshrined in the 1981 Manila Declaration on Tourism. This act emphasizes the inseparable link between tourism and the right of citizens to recreation, vacation and freedom of movement. The document pays special attention to social tourism, which is considered as a goal to which the society should strive to support youth tourism, tourism for the elderly and people with disabilities.

The objectives of social tourism are as follows:

- Development and implementation of excursion programs for senior citizens and people with disabilities as part of the stages of social tourism development;

- Meeting the needs of older citizens and people with disabilities in active recreation, boosting their interest in life, a sense of respect for oneself and society as a whole;

- Allocating some resources to ensure the promotion of certain tourist destinations;

- Overcoming social isolation;

- Initializing an interest in the history of the native land, getting acquainted with historical and architectural monuments;

- Holding cultural, entertaining and educational events;

- Prolongation of active life expectancy.

Social tourism can be implemented by any tourism organization, whose charter sets out the tasks of a social nature and aims not only to make a profit, but also to provide access to travel and tourism for the maximum number of people. For this purpose, the charter should provide:

- Unified solution of social, educational and cultural tasks;

- Defining a target audience regardless of racial, cultural, religious, political or social characteristics;

- Ensuring harmonious integration of social tourism with the local environment;

- Correspondence of tour product prices with the announced social prices. 
- Fulfilment of social tourism objectives requires:

- Finding sources of funding as long as making a profit for social tourism organizations is not the goal;

- Creating a new tangible base for social tourism or adapting the existing base to modern requirements;

- Development of a proper legislative and normative framework;

- Compliance of social tourism services with rising standards;

- Finding material assistance for social tourism clients;

- Establishing a conscientious financial system for low-income individuals who are eligible for benefits.

Therefore, social tourism is a sector of the tourism market, which is intended for the recipients of the funds allocated by the state.

\section{State regulation of social tourism development}

For the development of social tourism it is necessary to outline a long-term social program in the field of tourism.

Funds for social tours are often allocated directly to the beneficiaries. Many countries have already solved the problem of access to travel for people with disabilities. For example, in most European cities, transport is equipped with special elevators, and on tourist routes it is possible to travel by wheelchair.

Small travel agencies cannot afford to buy ramps or special buses for social needs, which are normally much more expensive than usual, so subsidies, to buy special equipment, would not be superfluous for tourism companies that offer social tourism to customers.

It is clear that business alone will not be able to solve the problem of travel infrastructure for people with disabilities since it involves significant investment. To create an environment without barriers in cities, market participants should consider the possibility of government subsidizing the arrangement of hotel rooms, restaurants and toilets, etc. for people with disabilities.

As the experience of foreign countries shows, a full-fledged sector of social tourism can be created only through the joint efforts of society, business and government agencies.

The social tourism system is a combination of social and cultural facilities and participants, as well as principles, goals, means, including benefits, which allow low-income segments of the population to enjoy the opportunities of tourist recreation. In order to ensure access to tourist recreation, it is necessary to develop a state social tourism policy, which aims to:

- Provide a legal framework;

- Adopt relevant regulations,

- Develop appropriate social infrastructure;

- Upskill qualified staff to organize information work and assist various segments of the population.

The social tourism system also provides a certain category of population not only with preferential vouchers, but also a significant discount on hotel accommodation, meals, as well as the benefit of purchasing tickets for various types of transportation. So, all over the world, there is a well-functioning system of youth hostels (cheap hotels such as student hostels) that allow young people under 25 to get significant discounts on accommodation, meals and travel.

Social tourism can be informational, recreational, rural, ecological, etc. Today, the most relevant direction in this field is agricultural, or agritourism, which gives residents of large cities the opportunity to visit the countryside, to get acquainted with the provincial life, and that of peasant farms. Typically, activities such 
as animation and masterclasses involve agritourism, which makes it possible to attractively present the traditions and customs of the region.

As mentioned, social tourism is funded by the state, foundations and social entrepreneurs.

As part of the state support, in Europe, the state provides subsidies. With this amount, social tour financing programs have been developed in the regions, for example, a solid amount of money is transferred to travel agencies every year and is distributed for social tours. The state regularly allocates grants for organizing social tours (usually aimed at organizing youth expeditions and children's tourism).

The foundations support programs in which non-budget funds and non-profit organizations as well as large enterprises create conditions for their employees to enjoy affordable rest. This also includes charitable programs and corporate social responsibility programs implemented in the field of tourism.

As for the social entrepreneurship, social entrepreneurs work to make tourism accessible to people with disabilities (students, orphanage graduates, large family members, low-income families) or for ones requiring special physical conditions and an accessible environment (people with disabilities). Social entrepreneurs increase access to travel services through an entrepreneurial approach and innovative solutions. Most social entrepreneurs participate in concessional loan and grant competitions at the same time to solve a business problem.

In this regard, the state policy in our country is under implementation and is still far from perfect. The problems of social tourism start with the fact of no regulatory documents in the tourism legislation to be in existence, specifying for certain tourists to enjoy budget funds for particular trips.

Currently, there is no law in Georgia on the implementation of a unified state policy on social tourism, offering the customers this very type of tourism. As for considering the needs of persons with disabilities, in this regard, there is the Law of Georgia on the Rights of Persons with Disabilities, which ensures the application of these and other powers provided by the Law of Georgia ${ }^{2}$.To ensure full access for people with disabilities, the National Tourism Administration of Georgia committed itself to gradually adapting to the universal design of the infrastructure and services, and/or design its own ones until December 31, 2035.

"People with disabilities belong to one of the most excluded groups. They still face pervasive obstacles in almost every area of public life. They do not have the opportunity to enjoy the rights enshrined in the Constitution on an equal footing with others. However, practice shows that one of the most pressing problems for people with disabilities remains access to public spaces, buildings, health care or public facilities and vehicles, educational and state institutions. This indicates that the standards set by the technical regulations are not actually put in practice" ${ }^{\text {. }}$.

The government has adopted the "Government Action Plan for Equal Opportunities for Persons with Disabilities 2018-2020". One of the directions of this Action Plan is the rights of persons with disabilities (Chapter 19). In this regard, the Action Plan for 2018-2020 envisages various measures, including ensuring equal participation of persons with disabilities in sports, cultural, recreational and entertainment activities ${ }^{4}$. Its content is fully in line with the principles of the UNCRPD Convention. This year, Tbilisi City Hall will provide voucher funding for hotel services at the resorts of Georgia for persons with disabilities aged 3 to 20 registered in the territory of Tbilisi Municipality in the previous year; the cost of the voucher amounts to 800 GEL; no less than 6 days are defined for rest; one voucher will be issued to the beneficiaries of the program for one year; the voucher can be used by a child or adolescent with a disability status of 3 to 20 years old, registered in the territory of Tbilisi Municipality. The beneficiary is entitled to choosing the hotel

\footnotetext{
${ }^{2}$ Law of Georgia on the Rights of Persons with Disabilities 28/07/2020https: //matsne.gov.ge/ka/document/view/4923984? Publication $=1$ [1. s. 05.11.2021].

${ }^{3} 2018$ Parliamentary Report on Human Rights and State of Protection of Rights and Freedoms in Georgia by the Public Defender of Georgia. p. 263. Tbilisi, 2019. Available: http://www.ombudsman.ge/res/docs/2019042620571319466.pdf [1. s. 09.12.2020].

${ }^{4} \mathrm{http}$ ://myrights.gov.ge/ka/discussion/1101-2018-2020-tslebis-samoqmedo-gegmis-proeqti [1.st checked on 12.10. 2021].
} 
and service terms". "The budget of the "Resort Services Program for Persons with Disabilities" amounts to 826,000 GEL. 1180 children enjoyed the mentioned service in the previous year"5.

The State Policy Document on the involvement of persons with disabilities into cultural, sporting, entertainment and recreational activities embraces the general approaches of the Convention; although, the indicators for the implementation of the planned actions and the budget are so general and vague that they do not allow effective implementation of the outlined activities ${ }^{6}$.

As of January 2020, the number of beneficiaries, receiving various state benefits (social package, state compensation, household subsidy) based on the status of a person with disabilities in Georgia, was 129,753, including 27,889 beneficiaries of social assistance payments ${ }^{7}$.

As of 2020, the share of the population below the absolute poverty line in Georgia is $21.3 \%$, which means that every fifth citizen of the country lives in extreme poverty, in other words, roughly 800000 individuals ${ }^{8}$.

According to the Social Service Agency, in 2020, an average of 484 thousand people received benefits every month. As of March of this year, 151000 families living in Georgia are receiving the allowance ${ }^{9}$. All this proves that a number of people urgently need social tourism programs.

\section{Foreign experience in the development of social tourism}

In European nations, the state regulates the social sector of tourism, directly through the Ministry of Tourism or National Tourism Organizations (NTOs), as well as indirectly by creating legal leverage, supporting social tourism infrastructure projects, etc. In many European countries, social tourism is organized by associations, cooperatives and trade unions with the aim of making travel available for as many people as possible, especially the least privileged. European projects have both international and national significance.

Calypso could be singled out as a successful example of good practice. There is an International Organization for Social Tourism (OITS) in Europe (Belgium). The following international organizations enjoy the OITS membership: International Federation of Social Tourism (headquartered in Paris), World Federation of Travel Agencies Associations (Milan), International Union for Conservation of Nature (Zurich), International Federation of Social Tourism Organizations (Brussels), International Tourism Alliance (Geneva), International Federation of Camping and Caravanning (Lucerne), International Hotel Association (Brussels), International Union of Railways (Paris). OITS aims to promote the development of social tourism internationally. To this end, it is responsible for coordinating the tourism activities of its members, as well as informing them about all issues related to social tourism, including cultural aspects and economic and social consequences ${ }^{10}$. More specifically, OITS, as an international non-profit association, aims to assist young people, families, the elderly and people with disabilities in leisure and tourist travel. It helps various stakeholders with achieving the mentioned goal, in particular, states, social actors and tour operators, as well as holding various competitions such as "Promoting Social Tourism in Europe through the Development of a Demand-Supply Web-Based Platform". The winner of the competition was the International Organization of Social Tourism (project manager) and the following partners: Club "Joie et Vacances" asbl (Flora Club), Belgium; the European Network for Accessible

\footnotetext{
${ }^{5}$ Resort services for children and adolescents with disabilities https://tbilisi.gov.ge/ [1. s. 12.10. 2021].

${ }^{6}$ shezghuduli-shesadzleblobis-mkone-bavshvtapirta-spetsializebuli-datsesebulebebis-monitoringis-angarishi

https://www.ombudsman.ge/geo/190308061623angarishebi/210916053235 [1. s. 22.09.21].

${ }^{7}$ Monitoring report of special institutions for children and persons with disabilities

https://www.ombudsman.ge/geo/190308061623angarishebi/210916053235 [1. s. 22.09.21];

${ }^{8} \mathrm{https} / /$ www.geostat.ge/ka/modules/categories/192/tskhovrebis-done (subsistence minimum) [1. s. 30.09.2021].

${ }^{9}$ https://www.geostat.ge/ka/modules/categories/192/tskhovrebis-done (subsistence minimum) [1. s. 30.09.2021].

${ }^{10}$ ORGANISATION INTERNATIONALE DU TOURISME SOCIAL (OITS) https://www.unwto.org/affiliate-memberorganization/41911[1. s. 30.09.2021].
} 
Tourism (ENAT), Belgium; the Union Nationale des Associations de Tourisme (UNAT), France; the National League of Cooperatives (LEGACOOP), Italy; Consortium "Siena Hotels Promotion", Italy; the State Technological Innovation Management Company for Tourism (SEGITTUR), Spain. "Promoting Seasonal Tourist Exchanges in Europe and the Mobility of Retirees" could be found to be an example of a successful project.

The goal of the projects implemented by the International Organization for Social Tourism is to create and develop a virtual platform of "Calypso" as a mechanism to facilitate access to international tourism, especially during the low season for the various target groups listed in the Calypso project program. It also aims to increase the competitiveness of small and medium-sized businesses in tourism and to expand the business opportunities of agents acting on behalf of their customers ${ }^{11}$.

Through this platform, the travel service provider can reach an agreement with hotels, restaurants and other travel businesses to create a comprehensive package offer. This package can be placed on the eCalypso platform and purchased there (the transaction is directly between the travel service provider and the buyer; the Calypso platform acts as an intermediary to facilitate contact between the two parties).

In Spain, there is a social tourism program that allows more than 1 million people of retirement age to take group trips each year. The Spanish government invests around $€ 75$ million a year in the program, which has created 10,000 additional jobs in the country, together with another successful program of "Tourism for the Old Generation".

The British program "Family Vacation" aims to ensure the vacation of low-income families to be no different from the vacation of richer families. Switzerland operates a program titled "Free Vacation Week for Single Mothers and Fathers". It provides 1,200 families and single parents with 50,000 free beds per day. Austria has a family card system, enabling to relax in the neighboring provinces of the country. Every family that wishes to spend a holiday with children gets a discount on the holidays. Discount service is provided by 1400 companies and institutions. 150000 people benefit from the project "Benefits for School Holidays and Weekends" each year. In Hungary, similar projects are aimed at improving the demographic situation as well as providing preferential recreational opportunities for expectant mothers. The Hungarian National Recreation Fund cooperates with 150 organizations and helps more than 100000 people on vacation time every year. The Czech Republic operates a program "Travel without Barriers" for people with disabilities.

\section{Measures to promote the development of social tourism}

Social tourism projects in our country can be implemented jointly in the Caucasus region as a whole, even by promoting seasonal tourism exchanges and tourist mobility. Since almost all regions of our country have the most important tourist and recreational potential, including cultural, educational, ethnographic and health tourism categories along with active leisure opportunities, Georgia has all the characteristics to become a social tourism leader in the region.

In addition to traditional tourist centers, all regions could be included. A tourism and recreational type project with special economic zones can be developed and implemented provided that its support is agreed with enterprises and organizations of several regions of Georgia, their governments and private entities. The project can be initiated by creating a supply and demand information field and its configuration can be defined in the interaction process. To start the project, it is necessary to attract the relevant tourism organizations and create a group of experts to prepare an appropriate platform. We think it is necessary to create a project with the title of "Social Tourism in Georgia", the funding of which is derived from the following reasons:

- Existence of serious social changes and economic problems;

\footnotetext{
${ }^{11} \mathrm{https}: / /$ issuu.com/turismosocial/docs/e-poster_isto [1. s. 30.09.2021].
} 
- Decreased life expectancy, financial difficulties and constraints, employment problems, lack of additional leisure time (stressful situations), which significantly affects the neighboring areas of tourism;

- The problems imposed by the quarantine and isolation modes intended to prevent the spread of the virus on persons with disabilities and their families. Health complications for people with Covid19 history throughout Georgia, who are in need of rehabilitation at a spa resort, especially when a large part of the country's population does not have the appropriate funds for recreation at various resorts.

It is advisable for the state to start outlining a preliminary project for the development of social tourism as a tool to achieve the following goals:

- Boosting employment;

- Extending season;

- Economic recovery at regional and local level.

The social tourism project should aim at recreation for the following categories of the population: the elderly, refugees, children, low-income families and people with disabilities. Many social tourism services should be provided in resorts, rural or mountainous areas. Social tourism exchanges can help combat seasonality, and developing regional and local economies.

Today travelers, especially young people, desire to get more complete information about the country, not only regarding the beautiful places but also about its people and their lifestyles. They wish to explore the country, share their culture, and while traveling, make a significant contribution to the economic development of the village, the region, with the money they spend on tourism services. Social tourism makes all this possible.

The state influences tourism in two ways: by managing demand and revenue, or by managing supply and prices. The state uses the following tools to manage demand: marketing, promotion, pricing, etc.

Social tourism promotion measures are an integral part of government marketing, and are designed to increase demand from potential customers. According to the WTO recommendations, all this is aimed at creating an image of the country based on its attractive symbolic characteristics. There are different ways to do this, such as organizing specialists' meetings with journalists, business trips abroad, TV and radio broadcastings, and free distribution of brochures, slides and video materials. Also, special support from the state can be given to the tourism enterprises that provide social tourism packages to participate in various exhibition and fairs; to help the representatives of the company in renting or arranging a stall.

There are various means by which the state can regulate the prices of tourism products, thus developing social tourism. This implies that, first of all, many sights in the country are in the sphere of influence of the public sector. For example, the ticket prices for the museums and museum-reserves, included in the structural unit of the National Agency for the Protection of Cultural Heritage of Georgia, have increased by almost 100\% since January 1, 2020. However, free access is available to: IDPs, war veterans, orphans and Georgian citizens with socially vulnerable status. Payment of the fee will also not apply to persons with disabilities and their accompanying citizens. ${ }^{12}$

The state can indirectly influence the price by using economic means, for example, by using currency controls, which can lead to restrictions on currency exchange, forcing tourists to exchange currency at high prices, and thus, increasing the real cost of travel, etc.

The state, in addition to the above-mentioned means, can influence the quality of a tourism product, even controlling demand through licensing. This measure is especially often exercised in relation to the hotel business.

\footnotetext{
${ }^{12}$ National Agency for Cultural Heritage Preservation https://www.heritagesites.ge/ka [1. s.30.10.2021].
} 
In order to regulate demand, some states are taking measures to restrict the entry of tourists, for example, reducing the number of visas, lessening the construction of hotels near natural attractions or closing the latter to protect the environment, etc.

Unlike demand management, which aims to select tourists and regulate prices, state regulation of supply management is related to the "impact" on the sellers of tourism services. In this regard, the state utilizes the following methods: market research and planning, market regulation, planning, land-use control mechanisms, housing regulation, taxes and investments. The state initiates market research, using statistical materials and monitors changes in tourism to determine tourism benefits and related costs.

The economic criterion that characterizes the optimal operation of the market is the consumer awareness about the alternatives offered to them. The state makes sure that consumers have a choice, are informed, and are insured against fraud by all types of sellers. The state is capable of regulating the market by imposing obligations on sellers in the form of legal norms, in the form of rules that apply to membership in various travel organizations. Ensuring a competitive environment and protecting the market from monopolization is made possible by the state through legal regulation of the market.

In many countries there are rules for the development of cities and regions, according to which land-use methods are changing and evolving. As a rule, state control is aimed at protecting unique tourist resources, protected areas, landscapes, etc. Land-use control is accompanied by construction regulation, and includes architectural supervision. Laws have been passed in many countries to protect historical and architectural monuments.

One of the main methods of influence of the state on tourism is to tax tourists. These are taxes imposed on tourists for accommodation in hotels, buying tickets at airports and casinos; however, the introduction of taxes may not always be favorable for the state, as tax collection, in turn, can reduce the demand for tourist services, and consequently, the revenue itself. For example, accommodation tax forces hotel owners to increase service prices, which can lead to a decrease in demand for hotel services, and consequently, the hotel revenue as well.

International investments in the tourism sector are provided by both international organizations and the private entities. The main foreign "donor" is the World Bank (International Bank for Reconstruction and Development IBRD). Its activities aim to ensure a normal standard of living in developing countries with particular emphasis on long-term funding for the development of infrastructure. Thus, in European countries, the state regulates the social tourism sector directly through the Ministry of Tourism or the National Tourism Organizations (NTOs), as well as indirectly through legal means, with the support of their infrastructure and international policies.

\section{Conclusion}

Social tourism is attached a great amount of importance in the modern, and it becomes the subject of attention and academic research. It possesses the ability to fulfil economic and humanitarian functions. In our country, social tourism services are not yet popular and available to all segments of the population. However, it is exactly the social tourism that is capable of providing everyone with good vacation opportunities, including people with disabilities.

Social tourism for the elderly is a new form of social service that aims to maintain health, organize proper and healthy recreation, expand the circle of communication, considering one's preferences and increase the robustness. Visiting interesting places or excursions produce vivid emotions and pleasant memories. Social tourism has become an important tool for overcoming the social loneliness of the elderly and people with disabilities; establishing, strengthening social ties and involving them in social activities.

Social tourism programs in different countries have already proven their relevance. Social tourism can make a huge contribution to human rights, health, rehabilitation, freedom of communication and movement. 
Social tourism allows a person to be in harmony with oneself, makes people's lives brighter and more positive, dignified, perfect; meets the cultural and spiritual needs of citizens. Social tourism can have different directions of development and, thus, enabling wide prospects for the implementation of this method.

The development of social tourism requires a thrust from the state, as the initiation of social programs involves the allocation of funds, especially at the stage of pilot projects, such as socialization of elderly and disabled citizens; developing social tourism routes, organizing tourist trips to the regions introducing citizens to the study of the history of the home country, expanding the boundaries of citizens' information and leisure boundaries.

It is necessary to prepare the tourist infrastructure for the development of social tourism. For example, people with disabilities need special equipment at airports, stairs, elevators, dry-cleaning and laundry facilities, accommodation facilities and rest rooms. In addition to the locals, there are many foreigners with disabilities, wishing to visit our country under social programs to visit the sights or get medical help. But technically, we are not able to properly host them, since hotels, transportation, or catering facilities in majority of tourist destinations throughout Georgia fail to be adequately equipped.

The problems of social tourism in Georgia start with the fact of no regulatory documents in the tourism legislation specifying the tourist category, eligible for receiving budget funds for certain types of tourist services.

It is necessary for the state to define social tourism policy in this regard, including the creation of social infrastructure, the adoption of legislative and normative acts, the provision of systems and mechanisms for assistance to low-income groups, and coaching social tourism system workers.

Social tourism should be implemented by any tourism organization, which aims not only to make a profit but also to provide access to travel and tourism for the maximum number of people available. For this purpose, the following should be considered: jointly solving social, educational and cultural tasks; defining a target audience regardless of racial, cultural, religious, political or social characteristics; ensuring harmonious integration of social tourism with the local environment; relevance of tour product prices with announced social prices.

The practical implementation of the tasks of social tourism requires finding sources of funding, as long as making a profit for social tourism organizations is not the goal; creating a new material base for social tourism or adapting the existing base to modern requirements; elaborating proper legislative and normative base; compliance of social tourism services with growing European standards; creating a conscientious financial system for low-income individuals who are eligible for benefits; active involvement of state, municipal, public and commercial entities into the development of tourism. 


\section{BIBLIOGRAPHY}

1. General condition of pensioners living below the poverty line, living alone. Research report. Tb. 2020. https://georgia.unfpa.org/ka/publications/covid-19-impact-on-lonely-older-people-Georgian. [Last seen 05.11.2021];

2. Social Service Agency (2020) Number of Social Package Recipients by Groups. http://ssa.gov.ge/index.php?lang_id=GEO\&sec_id [Last seen 30.09.2021];

3. Law of Georgia on the Rights of Persons with Disabilities https://matsne.gov.ge/ka/document/view/4923984?publication=1 [Last seen 05.11.2021];

4. The 2018 Parliamentary Report of the Public Defender of Georgia on the Situation of Human Rights and Freedoms in Georgia. P. 263. Tbilisi, 2019. http:/www.ombudsman.ge/res/docs/2019042620571319466.pdf [Last seen 07.09.2021];

5. http://myrights.gov.ge/ka/discussion/1101-2018-2020-tslebis-samoqmedo-gegmis-proeqti [Last seen 12.10. 2021];

6. Sub-program name: Resort Services for Children and Adolescents with Disabilities https://tbilisi.gov.ge/ [Last seen 05.11.2021];

7. Monitoring report of special institutions for children and persons with disabilities https://www.ombudsman.ge/geo/190308061623angarishebi/210916053235 [Last seen 22.09.21];

8. Subsistence minimum https://www.geostat.ge/ka/modules/categories/192/tskhovrebis-done [Last seen 30.09.2021];

9. Standard of living https://www.geostat.ge/ka/modules/categories/192/tskhovrebis-done [Last seen 30.09.2021];

10. ORGANISATION INTERNATIONALE DU TOURISME SOCIAL (OITS) https://www.unwto.org/affiliatemember-organization/41911 [Last seen 30.09.2021];

11. https://issuu.com/turismosocial/docs/e-poster_isto[Last seen 30.09.2021];

12. World Tourism Organization (UNWTO) UNWTO Declarations | Manila Declaration on World Tourism. (UNWTO), Madrid, Spain. 2221-6987; https://www.univeur.org/cuebc/downloads/PDF\%20carte/65.\%20Manila.PDF [Last seen 30.09.2021];

13. National Agency for Cultural Heritage Preservation. https://www.heritagesites.ge/ka. [Last seen 30.10.2021]. 